\title{
Selective Isolation of Mycobacteria from Soil: a Statistical Analysis Approach
}

\author{
By F. PORTAELS, ${ }^{*}$ A. DE MUYNCK ${ }^{1}$ AND M. P. SYLLA ${ }^{2}$ \\ ${ }^{1}$ Institute of Tropical Medicine, Nationalestraat 155, B-2000 Antwerpen, Belgium \\ 'Institut Marchoux, BP 251, Bamako, Mali
}

(Received 19 October 1987)

\begin{abstract}
We compared four decontamination methods for the isolation of mycobacteria from soil specimens. Different media were used: Löwenstein-Jensen, Ogawa and various modified Ogawa media. Statistical analysis demonstrated that the best results (low contamination and high positivity rates) were obtained when the specimens were incubated in trypticase soy broth, treated with solutions containing malachite green and cycloheximide, then decontaminated with sodium hydroxide and inoculated onto Ogawa media. The lowest contamination rates were obtained with Ogawa medium containing $500 \mu \mathrm{g}$ cycloheximide $\mathrm{ml}^{-1}$. The use of these techniques is proposed for the isolation of mycobacteria from heavily contaminated clinical specimens as well as from soil.
\end{abstract}

\section{INTRODUCTION}

The isolation of mycobacteria from specimens heavily contaminated with other microbes, such as soil, requires decontaminating procedures and selective media to overcome the multiplication of the other bacteria or fungi. Various methods have been described for the isolation of mycobacteria from environmental samples (see review by Songer, 1981). None of them are ideal, mostly due to the loss of cultures through growth of contaminants when the decontamination methods are too mild, or to the loss of mycobacteria when these methods are too drastic. Moreover, little information is available on the number of cultures which are lost due to contamination by other environmental micro-organisms.

During extensive studies of mycobacteria from the environment in Zaïre (Portaels, 1973, 1978,1980 ) and in the southeastern United States (F. Portaels, unpublished results), a large number of mycobacterial strains were isolated from soil samples. Different decontamination methods were used (Petroff, 1915; Corper \& Stoner, 1946; Kubica et al., 1963; Wolinsky \& Rynearson, 1968; Beerwerth \& Schurmann, 1969); those using NaOH (Petroff, 1915) and those using sodium hypochlorite (Kubica et al., 1963) were less effective than the other methods, mostly due to the loss of cultures by contamination (Portaels, 1978).

For the present study, the choice of decontamination methods was guided by those previous findings, and different media have been compared in order to find a procedure which will permit the isolation of high yields of mycobacteria from heavily contaminated specimens such as soil. A statistical analysis of the results is presented in detail since it enabled us to determine the optimum conditions for the isolation of mycobacteria from soil.

\section{METHODS}

Soil samples. A total of 35 soil samples (approximately $5 \mathrm{~g}$ each) were collected in the savannah around New Iberia (Louisiana, USA) in sterile plastic flasks.

Abbreviations: LJ, Löwenstein-Jensen medium; OG, Ogawa medium; O, Ogawa without malachite green; OGM, Ogawa with mycobactin; OGC, Ogawa with cycloheximide; OC, Ogawa without malachite green, with cycloheximide; OGN, Ogawa with $\mathrm{NaCl}$. 
Decontamination methods. Four decontamination methods were used. For method I, soil ( $0.5 \mathrm{~g}$, wet weight) was suspended in $5 \mathrm{ml}$ sterile water. The mixture was shaken vigorously. After allowing large particles to settle, the supernatant was collected and then treated with $10 \%(\mathrm{w} / \mathrm{v}) \mathrm{Na}_{3} \mathrm{PO}_{4}$ as described by Corper \& Stoner (1946).

For method II, soil $(0.5 \mathrm{~g}$, wet weight) was suspended in sterile water as in method I and treated first with $\mathrm{NaOH}$ and subsequently with oxalic acid as described by Beerwerth \& Schurmann (1969).

Method III is a modification of the method of Wolinsky \& Rynearson (1968). To $0.5 \mathrm{~g}$ soil (wet weight), $5 \mathrm{ml}$ sterile trypticase soy broth was added. The mixture was shaken vigorously and incubated at $37^{\circ} \mathrm{C}$ for $5 \mathrm{~h}$ to allow spore-forming bacteria to germinate so that they would be killed by the subsequent treatments. To the supernatant were added $5 \mathrm{ml} 0.2 \%$ malachite green, $1 \mathrm{ml}$ cycloheximide $\left(500 \mu \mathrm{g} \mathrm{ml}^{-1}\right)$ and $5 \mathrm{ml} 1 \mathrm{M}-\mathrm{NaOH}$. After $30 \mathrm{~min}$ at room temperature the mixture was neutralized with $1 \mathrm{M}-\mathrm{HCl}$, then centrifuged at $2000 \mathrm{~g}$ for $15 \mathrm{~min}$. The supernatant was discarded and the sediment was inoculated onto different media.

Method IV results from the combination of methods II and III. To $0.5 \mathrm{~g}$ soil, sterile solutions of $0.2 \%$ malachite green $(5 \mathrm{ml})$ and cycloheximide $\left(1 \mathrm{ml}\right.$ at $\left.500 \mu \mathrm{g} \mathrm{m}^{-1}\right)$ were added, and the mixture was shaken vigorously. After settling, $5 \mathrm{ml} 1 \mathrm{M}-\mathrm{NaOH}$ was added to the supernatant. After $30 \mathrm{~min}$ at room temperature the mixture was centrifuged at $2000 \mathrm{~g}$ for $15 \mathrm{~min}$. The supernatant was discarded and the residue suspended in $10 \mathrm{ml}$ oxalic acid $(5 \%, \mathrm{w} / \mathrm{v})$. The mixture was kept at room temperature for $30 \mathrm{~min}$ and then centrifuged at $2000 \mathrm{~g}$ for $15 \mathrm{~min}$. The supernatant was discarded. The sediment was washed with sterile distilled water, and then inoculated onto different media.

Growth media. Each treated sample was inoculated onto two reference media: Löwenstein-Jensen (LJ) medium and Ogawa (OG) medium (Pattyn \& Portaels, 1980) and onto different Ogawa media modified as follows: Ogawa medium without malachite green $(\mathrm{O})$; Ogawa medium supplemented with mycobactin from Mycobacterium smegmatis (prepared and kindly supplied by Dr R. Hall, University of Hull, UK) at a final concentration of $40 \mu \mathrm{g} \mathrm{ml}^{-1}$ (OGM); Ogawa medium containing cycloheximide (Sigma) at a final concentration of $500 \mu \mathrm{g} \mathrm{ml}^{-1}$ (OGC). Ogawa medium without malachite green containing cycloheximide $\left(500 \mu \mathrm{g} \mathrm{ml}^{-1}\right.$, final concentration) (OC); Ogawa medium supplemented with $\mathrm{NaCl}(1 \%$ w/v) (OGN).

In general, two tubes of each medium were inoculated with each treated soil sample. However, a few samples were not inoculated onto all the media, due to operational difficulties in the field.

Incubation of mycobacteria. The inoculated media were incubated at $30^{\circ} \mathrm{C}$ for 6 months and observed every fortnight. In every tube suspected of being positive for mycobacterial growth, some colonies were selected and separately subcultured on the same medium as the primary culture; the colonies were checked for acid fastness by Ziehl-Neelsen staining.

The mycobacterial strains isolated were identified as described by Jenkins et al. (1982), but their identity will not be described here as it is not relevant.

Statistical analysis. The following three parameters were studied: (i) the contamination rate (number of contaminated tubes/total number of tubes inoculated); (ii) the positivity rate (number of positive tubes/total number of uncontaminated tubes); and (iii) the overall positivity rate (number of positive tubes/total number of inoculated tubes). Rate ratios were calculated as the ratio between the contamination or positivity rate in the method or medium that has to be assessed, and the corresponding rate in the reference medium and method. Statistical tests used were the $\chi^{2}$ test or, when required, a Fisher's exact test. If the statistical test result was significant, then the $95 \%$ unilateral confidence limit around the rate ratio was calculated, using the test-based approach (Miettinen, 1976).

\section{RESULTS}

The number of contaminated and positive cultures and the total number of inoculated tubes are indicated, for each method and each medium, in Tables 1 to 6 . The number of mycobacterial colonies in the positive cultures varied between one and ten.

\section{Comparison of $L J$ and $O G$ media}

For this comparison all four decontamination methods (I, II, III, IV) were used. As indicated in Table 1, contamination rate was higher on $\mathrm{LJ}$ than on OG for each of the decontamination methods. The overall ratio of the contamination rate on $\mathrm{LJ}$ versus that on $\mathrm{OG}$ was $1 \cdot 40$. Thus the contamination rate of the test tubes containing $\mathrm{LJ}$ was $40 \%$ higher than those with OG $(P<0.01)$. The unilateral $95 \%$ confidence limit was $1 \cdot 12$; therefore if this work should be repeated, on $95 \%$ of occasions the contamination rate would be at least $12 \%$ higher in isolates grown on $\mathrm{LJ}$ than in isolates grown on $\mathrm{OG}$.

The ratio of the positivity rate of tests on LJ versus that of tests on OG was 0.92 (Table 2). Thus, the positivity rate on $\mathrm{LJ}$ was $8 \%$ less than that on $\mathrm{OG}$, but this was not significant $(P>0.05)$. However, the overall positivity rate (Table 3$)$ was much higher on $O G$, and was 
Table 1. Contamination rate of $L J$ versus $O G$

\begin{tabular}{|c|c|c|c|c|c|c|c|}
\hline \multirow[b]{3}{*}{$\begin{array}{l}\text { Decontamination } \\
\text { method }\end{array}$} & \multicolumn{3}{|c|}{ LJ medium } & \multicolumn{3}{|c|}{ OG medium } & \multirow[b]{3}{*}{$\begin{array}{c}\text { Ratio } \\
\% \mathrm{LJ} / \% \mathrm{OG}\end{array}$} \\
\hline & \multirow[b]{2}{*}{$\begin{array}{l}\text { Total } \\
\text { tubes }\end{array}$} & \multicolumn{2}{|c|}{ Contamination } & \multirow[b]{2}{*}{$\begin{array}{l}\text { Total } \\
\text { tubes }\end{array}$} & \multicolumn{2}{|c|}{ Contamination } & \\
\hline & & $\begin{array}{l}\text { No. of } \\
\text { tubes }\end{array}$ & $\begin{array}{c}\text { Rate } \\
(\%)\end{array}$ & & $\begin{array}{l}\text { No. of } \\
\text { tubes }\end{array}$ & $\begin{array}{c}\text { Rate } \\
(\%)\end{array}$ & \\
\hline I $\left(\mathrm{Na}_{3} \mathrm{PO}_{4}\right)$ & 56 & 32 & (57) & 56 & 18 & (32) & $1 \cdot 78$ \\
\hline II ( $\mathrm{NaOH} /$ oxalic acid) & 56 & 32 & (57) & 56 & 26 & $(46)$ & $1 \cdot 23$ \\
\hline $\begin{array}{l}\text { III* (malachite green/cycloheximide/ } \\
\mathrm{NaOH} \text { ) }\end{array}$ & 45 & 10 & (22) & 43 & 6 & (14) & 1.59 \\
\hline $\begin{array}{l}\text { IV (malachite green/cycloheximide/ } \\
\mathrm{NaOH} / \text { oxalic acid) }\end{array}$ & 42 & 12 & (29) & 42 & 11 & (26) & 1.09 \\
\hline Total & 199 & 86 & $(43)$ & 197 & 61 & $(31)$ & $1.40 \dagger$ \\
\hline
\end{tabular}

* Incubation in trypticase soy broth before decontamination.

$+\chi^{2}(1)=6.35 ; P<0.01$.

Table 2. Positivity rate on $L J$ versus $O G$

\begin{tabular}{|c|c|c|c|c|c|c|c|}
\hline \multirow[b]{3}{*}{$\begin{array}{c}\text { Decontamination } \\
\text { method }\end{array}$} & \multicolumn{3}{|c|}{ LJ medium } & \multicolumn{3}{|c|}{ OG medium } & \multirow[b]{3}{*}{$\begin{array}{c}\text { Ratio } \\
\% \mathrm{LJ} / \% \mathrm{OG}\end{array}$} \\
\hline & \multirow{2}{*}{$\begin{array}{c}\text { Total } \\
\text { uncontam. } \\
\text { tubes }\end{array}$} & \multicolumn{2}{|c|}{ Positivity } & \multirow{2}{*}{$\begin{array}{c}\text { Total } \\
\text { uncontam. } \\
\text { tubes }\end{array}$} & \multicolumn{2}{|c|}{ Positivity } & \\
\hline & & $\begin{array}{l}\text { No. of } \\
\text { tubes }\end{array}$ & $\begin{array}{c}\text { Rate } \\
(\%)\end{array}$ & & $\begin{array}{l}\text { No. of } \\
\text { tubes }\end{array}$ & $\begin{array}{l}\text { Rate } \\
(\%)\end{array}$ & \\
\hline $\mathrm{I}\left(\mathrm{Na}_{3} \mathrm{PO}_{4}\right)$ & 24 & 17 & $(71)$ & 38 & 30 & (79) & 0.90 \\
\hline II (NaOH/oxalic acid) & 24 & 19 & $(79)$ & 30 & 23 & $(77)$ & 1.03 \\
\hline $\begin{array}{l}\text { III }^{*} \text { (malachite green/cycloheximide/ } \\
\mathrm{NaOH})\end{array}$ & 35 & 27 & (77) & 37 & 35 & (95) & 0.82 \\
\hline $\begin{array}{l}\text { IV (malachite green/cycloheximide/ } \\
\mathrm{NaOH} / \text { oxalic acid) }\end{array}$ & 30 & 26 & $(87)$ & 31 & 28 & $(90)$ & 0.96 \\
\hline Total & 113 & 89 & $(79)$ & 136 & 116 & $(85)$ & $0.92 \dagger$ \\
\hline
\end{tabular}

Table 3. Overall positivity rate on $L J$ versus $O G$

\begin{tabular}{|c|c|c|c|c|c|c|c|}
\hline \multirow[b]{3}{*}{$\begin{array}{l}\text { Decontamination } \\
\text { method }\end{array}$} & \multicolumn{3}{|c|}{ LJ medium } & \multicolumn{3}{|c|}{ OG medium } & \multirow[b]{3}{*}{$\begin{array}{c}\text { Ratio } \\
\% \mathrm{LJ} / \% \mathrm{OG}\end{array}$} \\
\hline & \multirow[b]{2}{*}{$\begin{array}{l}\text { Total } \\
\text { tubes }\end{array}$} & \multicolumn{2}{|c|}{ Positivity } & \multirow[b]{2}{*}{$\begin{array}{l}\text { Total } \\
\text { tubes }\end{array}$} & \multicolumn{2}{|c|}{ Positivity } & \\
\hline & & $\begin{array}{l}\text { No. of } \\
\text { tubes }\end{array}$ & $\begin{array}{c}\text { Rate } \\
(\%)\end{array}$ & & $\begin{array}{l}\text { No. of } \\
\text { tubes }\end{array}$ & $\begin{array}{c}\text { Rate } \\
(\%)\end{array}$ & \\
\hline $\mathrm{I}\left(\mathrm{Na}_{3} \mathrm{PO}_{4}\right)$ & 56 & 17 & $(30)$ & 56 & 30 & (53) & 0.56 \\
\hline II $(\mathrm{NaOH} /$ oxalic acid $)$ & 56 & 19 & (34) & 56 & 23 & (41) & 0.83 \\
\hline $\begin{array}{l}\mathrm{III}^{*} \text { (malachite green/cycloheximide/ } \\
\mathrm{NaOH})\end{array}$ & 45 & 27 & $(60)$ & 43 & 35 & $(81)$ & $0 \cdot 74$ \\
\hline $\begin{array}{l}\text { IV (malachite green/cycloheximide/ } \\
\mathrm{NaOH} / \text { oxalic acid) }\end{array}$ & 42 & 26 & $(62)$ & 42 & 28 & $(67)$ & 0.93 \\
\hline Total & 199 & 89 & $(45)$ & 197 & 116 & $(59)$ & $0.76+$ \\
\hline
\end{tabular}

* Incubation in trypticase soy broth before decontamination.

$\dagger \chi^{2}(1)=7.93 ; P<0.01$. 
consistently higher regardless of the decontamination method used. This difference was highly significant $(P<0.01)$. Therefore, in the following study, growth on OG was used to compare the effect of decontamination methods and as the baseline to compare the effect of modifications to the growth medium.

\section{Comparison of the decontamination methods}

Although the decision was made not to use $\mathrm{LJ}$ after preliminary work, that preliminary work included a comparison of the four decontamination methods prior to inoculation of samples onto LJ. For the sake of completeness, the results are presented in this section. There was significantly less contamination (Table 1) after decontamination by methods III and IV than after decontamination by methods I and II. However, there was no significant difference in decontamination between methods III and IV. All four decontamination methods produced similar positivity rates (Table 2), there being no significant difference between methods I, II, III and IV. The overall positivity rate (Table 3 ) was significantly higher for methods III and IV than for methods I and II. There was no significant difference between methods III and IV.

When samples were inoculated onto OG, the following results were obtained.

Contamination rate. There was no significant difference between the contamination rates after decontamination by the four methods (Table 1).

Positivity rate. As shown in Table 2, on OG, there was a significant difference between the relative frequency of positive results between methods III $(95 \%)$ and II $(77 \%)\left(\chi^{2}=11.6\right.$; $P<0.01)$, and between methods III $(95 \%)$ and I $(79 \%)\left(\chi^{2}=4.3 ; P<0.05\right)$. There was no significant difference between methods IV $(90 \%)$ and III $(95 \%)\left(\chi^{2}=1.97 ; P>0.05\right)$.

Overall positivity rate. As shown in Table 3, there was a significant difference between methods III $(81 \%)$ and II $(41 \%)\left(\chi^{2}=16 ; P<0.001\right)$ and between methods III $(81 \%)$ and I $(53 \%)\left(\chi^{2}=6.8 ; P<0.01\right)$. There was no significant difference between methods IV $(67 \%)$ and III $(81 \%)\left(\chi^{2}=2.4 ; P>0.05\right)$.

In order to find out the one best decontamination method, methods III and IV were next compared using Ogawa medium and modified Ogawa media.

\section{Comparison of decontamination methods III and IV using Ogawa and Ogawa-based media}

Contamination rate. The contamination rate for each medium is shown in Table 4 . When results for inoculation onto all six media were pooled, there were at least $33 \%$ fewer contaminated tubes with method III than with method IV $\left(\chi^{2}=7 \cdot 47 ; P<0.01\right)$.

Positivity rate. There was no significant difference in the positivity rates between methods IV and III $\left(\chi^{2}=1.5 ; P>0.05\right)$ (Table 5).

Overall positivity rate. When results with all six media were pooled, the overall positivity rate was significantly higher for samples which were decontaminated by method III rather than by method IV (Table 6). The overall positivity rate was $20 \%$ higher with method III than with method IV $\left(\chi^{2}=7.9 ; P<0.01\right)$.

These results showed method III to be the most satisfactory decontamination procedure.

\section{Comparison of the various Ogawa-based media using decontamination method III}

To ascertain the best growth medium, rates of contamination and positivity were compared for samples decontaminated by method III, between five modified Ogawa media and Ogawa medium (OG). Since the objective was to find a better medium than OG, $P$ values were only calculated when the rate ratio was less than one (i.e. less contamination than in the reference OG) in the case of the contamination rate (Table 4) and equal or greater than one in the case of the positivity rate (Table 5) or the overall positivity rate (Table 6).

Contamination rate. Only on one medium, OGC, was there significantly less contamination $(P=0.0017$, Fisher's exact test) than on OG (Table 4). 
Table 4. Contamination rate on different Ogawa media after decontamination methods III and IV

\begin{tabular}{|c|c|c|c|c|c|c|c|}
\hline & & Method & & & Method & & \\
\hline & & Cont: & tion & & Conta & tion & \\
\hline Medium & $\begin{array}{l}\text { Total } \\
\text { tubes }\end{array}$ & $\begin{array}{l}\text { No. of } \\
\text { tubes }\end{array}$ & $\begin{array}{c}\text { Rate } \\
(\%)\end{array}$ & $\begin{array}{l}\text { Total } \\
\text { tubes }\end{array}$ & $\begin{array}{l}\text { No. of } \\
\text { tubes }\end{array}$ & $\begin{array}{c}\text { Rate } \\
(\%)\end{array}$ & $\begin{array}{l}\text { Ratio } \\
\% \text { III } / \% \text { IV }\end{array}$ \\
\hline OG & 42 & 11 & (26) & 43 & 6 & (14) & 0.53 \\
\hline $\mathrm{O}$ & 27 & 25 & (93) & 27 & 17 & (63) & 0.68 \\
\hline OGM & 47 & 14 & (30) & 47 & 7 & (15) & 0.50 \\
\hline $\mathrm{OC}$ & 36 & 18 & (50) & 37 & 18 & (49) & 0.97 \\
\hline OGC & 46 & 6 & (13) & 45 & 2 & (4) & 0.34 \\
\hline OGN & 46 & 9 & (20) & 46 & 6 & (13) & 0.67 \\
\hline Total & 244 & 83 & (34) & 245 & 56 & (23) & $0.67 \ddagger$ \\
\hline
\end{tabular}

* Decontamination with malachite green, cycloheximide, $\mathrm{NaOH}$ and oxalic acid.

$\dagger$ Incubation in trypticase soy broth followed by decontamination with malachite green, cycloheximide and $\mathrm{NaOH}$

$\ddagger \chi^{2}(1)=7.47 ; P<0.01$

Table 5. Positivity rate on different Ogawa media after decontamination methods III and IV

\begin{tabular}{|c|c|c|c|c|c|c|c|}
\hline \multirow[b]{3}{*}{ Medium } & \multicolumn{3}{|c|}{ Method IV* } & \multicolumn{3}{|c|}{ Method III $\dagger$} & \multirow[b]{3}{*}{$\begin{array}{c}\text { Ratio } \\
\% \mathrm{III} / \% \mathrm{IV}\end{array}$} \\
\hline & \multirow{2}{*}{$\begin{array}{c}\text { Total } \\
\text { uncontam. } \\
\text { tubes }\end{array}$} & \multicolumn{2}{|c|}{ Positivity } & \multirow{2}{*}{$\begin{array}{c}\text { Total } \\
\text { uncontam. } \\
\text { tubes }\end{array}$} & \multicolumn{2}{|c|}{ Positivity } & \\
\hline & & $\begin{array}{l}\text { No. of } \\
\text { tubes }\end{array}$ & $\begin{array}{c}\text { Rate } \\
(\%)\end{array}$ & & $\begin{array}{l}\text { No. of } \\
\text { tubes }\end{array}$ & $\begin{array}{l}\text { Rate } \\
(\%)\end{array}$ & \\
\hline OG & 31 & 28 & $(90)$ & 37 & 35 & (95) & 1.05 \\
\hline 0 & 2 & 2 & (100) & 10 & 10 & (100) & 1.00 \\
\hline OGM & 33 & 29 & $(88)$ & 40 & 37 & (93) & 1.05 \\
\hline OC & 18 & 15 & (83) & 19 & 18 & (95) & $1 \cdot 14$ \\
\hline OGC & 40 & 36 & (90) & 43 & 41 & (95) & 1.06 \\
\hline OGN & 37 & 35 & (95) & 40 & 36 & (90) & 0.95 \\
\hline Total & 161 & 145 & (90) & 189 & 177 & (94) & $1.04 \ddagger$ \\
\hline
\end{tabular}

* Decontamination with malachite green, cycloheximide, $\mathrm{NaOH}$ and oxalic acid.

$\dagger$ Incubation in trypticase soy broth followed by decontamination with malachite green, cycloheximide and $\mathrm{NaOH}$.

$\ddagger \chi^{2}(1)=1.5 ; P>0.05$.

Table 6. Overall positivity rate on different Ogawa media after decontamination methods III and $I V$

$\begin{array}{lccc}\text { Medium } & \begin{array}{c}\text { Total } \\ \begin{array}{c}\text { uncontam. } \\ \text { tubes }\end{array}\end{array} & \overbrace{\begin{array}{c}\text { No. of } \\ \text { tubes }\end{array}}^{\text {Positivity }} & \begin{array}{c}\text { Rate } \\ (\%)\end{array} \\ \text { OG } & 41 & 28 & (68) \\ \text { O } & 25 & 2 & (8) \\ \text { OGM } & 47 & 29 & (62) \\ \text { OC } & 36 & 15 & (42) \\ \text { OGC } & 46 & 36 & (78) \\ \text { OGN } & 46 & 35 & (76) \\ \text { Total } & 241 & 145 & (60)\end{array}$

\begin{tabular}{|c|c|c|c|}
\hline \multicolumn{3}{|c|}{ Method III $†$} & \multirow[b]{3}{*}{$\begin{array}{l}\text { Ratio } \\
\% \text { III } / \% \text { IV }\end{array}$} \\
\hline \multirow{2}{*}{$\begin{array}{c}\text { Total } \\
\text { uncontam. } \\
\text { tubes }\end{array}$} & \multicolumn{2}{|c|}{$\underbrace{\text { Positivity }}$} & \\
\hline & $\begin{array}{l}\text { No. of } \\
\text { tubes }\end{array}$ & $\begin{array}{c}\text { Rate } \\
(\%)\end{array}$ & \\
\hline 43 & 35 & (81) & $1 \cdot 19$ \\
\hline 27 & 10 & (37) & 4.63 \\
\hline 47 & 37 & (79) & 1.28 \\
\hline 37 & 18 & (49) & 1.17 \\
\hline 45 & 41 & $(91)$ & $1 \cdot 16$ \\
\hline 46 & 36 & (78) & 1.03 \\
\hline 245 & 177 & $(72)$ & $1 \cdot 20 \ddagger$ \\
\hline
\end{tabular}

* Decontamination with malachite green, cycloheximide, $\mathrm{NaOH}$ and oxalic acid.

† Incubation in trypticase soy broth followed by decontamination with malachite green, cycloheximide and $\mathrm{NaOH}$.

$\ddagger \chi^{2}(1)=7.9 ; P<0.01 ;$ unilateral $95 \%$ confidence limit $=1 \cdot 08$. 
Positivity rate. Only on one medium, $\mathrm{O}$, was there a higher positivity rate (Table 5) than on OG, but the difference was not statistically significant. OC and OGC media gave the same results as OG; the other two media gave a lower positivity rate.

Overall positivity rates. OGC medium gave a better overall result than $\mathrm{OG}$, but the difference was not statistically significant (Table 6).

\section{DISCUSSION}

The superiority of OG compared to LJ might be partially related to the $\mathrm{pH}$ of the media (pH 6 for $\mathrm{OG}$ and $\mathrm{pH} 7$ for $\mathrm{LJ}$ ). Although most mycobacterial species do grow at $\mathrm{pH} 7$, mycobacteria grow optimally at a lower pH (Chapman \& Bernard, 1962; Portaels \& Pattyn, 1982; George \& Falkinham, 1985). Therefore, the Ogawa medium with a $\mathrm{pH}$ of 6 seems to be more appropriate for the primary isolation of mycobacteria from environmental, animal or human sources (Portaels \& Pattyn, 1981; Portaels et al., 1982, 1985).

The present study on soil specimens showed that addition of mycobactin did not significantly enhance positivity. However, in other studies the inclusion of mycobactin for the isolation of mycobacteria from specimens from diseased humans or animals significantly enhanced the positivity and allowed the isolation of some strains which were missed with other media (Thoen et al., 1979; Portaels et al., 1982, 1985).

Several authors have used malachite green to decontaminate environmental samples (Beerwerth, 1967; Wolinsky \& Rynearson, 1968; Goslee \& Wolinsky, 1976). However, although most mycobacterial species are not inhibited by malachite green, a few are (Portaels et al., 1986). Therefore, media without malachite green should also be used for the isolation of mycobacteria from environmental or clinical samples.

This study also shows that when mycobacteria are cultivated from soil specimens, both pretreatment with cycloheximide (as in decontamination methods III and IV) and the addition of this antifungal antibiotic to Ogawa medium (OGC) are effective in preventing contamination by fungi. But cycloheximide was found ineffective in preventing fungal growth from sputum (Corper \& Cohn, 1952) and from bovine faeces (Merkal \& Richards, 1972). Additional studies are necessary to determine the susceptibility of mycobacteria to cycloheximide.

From the present statistical analysis, it may be concluded that the best results (low contamination and high positivity rates) were obtained when the specimens were incubated in trypticase soy broth, then treated with solutions containing malachite green and cycloheximide, decontaminated with sodium hydroxide (method III) and inoculated onto Ogawa media. The lowest contamination rates were obtained with Ogawa medium containing $500 \mu \mathrm{g}$ cycloheximide $\mathrm{ml}^{-1}$. Tests are currently under way to determine whether the best methods and media described here can also be used for the isolation of mycobacteria from other heavily infected specimens, e.g. human faeces. This would be very useful for detection of mycobacteria from patients with acquired immunodeficiency syndrome.

This work was supported by the Damien Foundation (Brussels). We wish to thank Miss I. Billen, Miss K. Fissette and Mrs K. De Ridder for excellent technical assistance. We also thank Mrs Y. Baeten for preparation of the manuscript.

\section{REFERENCES}

BEERWERTH, W. (1967). Culture of mycobacteria from the droppings of domestic animals and the role of these bacteria in epizootiology. Praxis in Pneumology 21, 189-202.

Beerwerth, W. \& SchurmanN, J. (1969). Zür Okologie der Mycobakterien. Zentralblatt für Bakteriologie (I Abt., Orig.) 211, 58-69.

Chapman, J. S. \& BernaRd, J. S. (1962). The tolerances of unclassified mycobacteria. 1. Limits of the $\mathrm{pH}$ tolerance. American Review of Respiratory Diseases 86, 582-583.
Corper, H. J. \& CohN, M. L. (1952). Cycloheximide (antibiotic Actidione) as a fungicide in solid media for growing tubercule bacilli from sputum. Antibiotics and Chemotherapy 2, 12-15.

CORPER, H. J. \& STONER, R. E. (1946). An improved procedure for diagnostic culture of mammalian tubercle bacilli. Journal of Laboratory and Clinical Medicine 31, 1364-1370.

GeORGE, K. L. \& FalkinhaM, J. O., III (1985). Selective medium for the isolation and enumeration of Mycobacterium avium-intracellulare and $M$. 
scrofulaceum. Canadian Journal of Microbiology 32, 10-14.

GoSLEE, S. \& WoLINSKY, S. (1976). Water as a source of potentially pathogenic mycobacteria. American Review of Respiratory Diseases 113, 287-292.

Jenkins, P. A., Pattyn, S. R. \& Portaels, F. (1982). Diagnostic bacteriology. In The Biology of the Mycobacteria, pp. 441-471. Edited by C. Ratledge \& J. L. Stanford. London: Academic Press.

Kubica, G. P., Beam, R. E. \& Palmer, J. W. (1963). A method for the isolation of unclassified acid-fast bacilli from soil and water. American Review of Respiratory Diseases 88, 718-720.

MERKAL, R. S. \& RichaRdS, W. D. (1972). Inhibition of fungal growth in the cultural isolation of mycobacteria. Applied Microbiology 24, 205-207.

MietTinen, O. S. (1976). Estimability and estimation in case referent studies. American Journal of Epidemiology 103, 226-235.

Pattyn, S. R. \& Portaels, F. (1980). In vitro cultivation and characterization of Mycobacterium lepraemurium. International Journal of Leprosy 48, 714.

Petroff, S. A. (1915). A new and rapid method for the isolation and cultivation of tubercle bacilli directly from the sputum and feces. Journal of Experimental Medicine 21, 38-42.

Portaels, F. (1973). Contribution à l'étude des mycobactéries de l'environnement au Bas-Zaïre. Annales de la Société belge de médecine tropicale 53, 373-387.

PORTAELS, F. (1978). Etude d'Actinomycétales isolées de l'homme et de son environnement en Afrique Centrale. Doctoral thesis, University of Brussels, Belgium.
Portaels, F. (1980). Etude de mycobactéries isolées de l'homme et de son environnement au Zaïre. Annales de microbiologie 131A, 18-19.

Portaels, F. \& PatTyn, S. R. (1981). Parameters influencing the 'in vitro' growth of Mycobacterium lepraemurium. International Journal of Leprosy 49, 194-197.

Portaels, F. \& Pattyn, S. R. (1982). Growth of mycobacteria in relation to the $\mathrm{pH}$ of the medium. Annales de microbiologie 133B, 213-221.

Portaels, F., Francken, A. \& Pattyn, S. R. (1982). Bacteriological studies of armadillo livers infected with Mycobacterium leprae. Annales de la Société belge de médecine tropicale 62, 233-245.

Portaels, F., De Ridder, K. \& Pattyn, S. R. (1985). Cultivable mycobacteria isolated from organs of armadillos uninoculated and inoculated with $\mathrm{Myco}$ bacterium leprae. Annales de l'Institut Pasteur/Microbiologie 136A, 181-190.

SONGER, J. G. (1981). Methods for selective isolation of mycobacteria from the environment. Canadian Journal of Microbiology 27, 1-7.

Thoen, C. O., Himes, E. M., Jarnagin, J. L. \& HARRINGTON, R. (1979). Comparison of four culture media for isolation of Mycobacterium avium complex from porcine tissues. Journal of Clinical Microbiology 9, 194-196.

Wolinsky, E. \& Rynearson, T. K. (1968). Mycobacteria in soil and their relation to diseases-associated strains. American Review of Respiratory Diseases 97, 1032-1037. 